Univerzitet u Beogradu https://doi.org/10.18485/zivjez.2019.39.1.7 Filološki fakultet

\title{
U POTRAZI ZA IZGUBLJENIM RAJEM: BREND GRČKE U REKLAMNOM DISKURSU SRPSKIH TURISTIČKIH AGENCIJA
}

Polazeći od činjenice da je za turiste iz Srbije Grčka i dalje neprikosnovena destinacija za letovanje, u ovom radu se ispituje jezik u reklamnom diskursu srpskih turističkih agencija kada je u pitanju promocija brenda Grčke. U prvom delu empirijskog istraživanja kvantitativnom metodom se u korpusu odabranih tekstova identifikuju najfrekventnije imenice, pridevi i glagoli, a zatim se klasifikuju po odgovarajućim semantičkim poljima. U drugom delu se identifikuju sintagme u kojima se neke od tih reči najčešće javljaju, kako bi se ispitala njihova upotreba u različitim kontekstima koji su uslovljeni kombinacijom različitih semantičkih polja, i da li i u kojoj meri su njihova značenja promenjena upotrebom elemenata figurativnog jezika u promotivne svrhe.

Ključne reči: reklamni diskurs, jezik turizma, destinacija, brendiranje, analiza korpusa, semantičko polje

\section{Uvod}

U eri globalizacije i ekspanzije turizma kao najmasovnije društveno-ekonomske pojave, „turisti putuju oko čitave Zemljine kugle da bi bili u prisustvu naroda, mesta i objekata koje ne mogu kupiti ili ih drugačije posedovati osim u duhovnom smislu“ (Mek Kanel 2002: 146). Prema rečima Haleta i Kaplan-Vajnger (2010: 12), u Sjedinjenim Američkim Državama putovanje se posmatra kao „beg od svega“, „doživljavanje drugih svetova“ ili „širenje horizonata“. Ono predstavlja rezultat potrage za razonodom, relaksacijom, zabavom ili obrazovanjem. Ideologija putovanja i turizma kao narativ

*_dina_dotlic@hotmail.com 
daje smernice pri izboru mesta koja će se posetiti, onoga što će se raditi ili videti, pa čak i koje će uspomene ostati i kasnije se evocirati. Pojedinac želi da bude deo tog narativa i da mu se prilagodi, oblikujući i preoblikujući svoj identitet.

Kada je reč o masovnom turizmu, Obrador-Pons i dr. (2009: 2) navode da je često definisan u suprotnosti sa klasičnim idejama o putovanju i obilasku znamenitosti. Naime, ova vrsta turizma se vezuje za toplu klimu, zadovoljstva na obali, rasterećenost od obaveza, relaksaciju i atmosferu za zabavu. Masovni turizam predstavlja drugačije turističko iskustvo koje sa tri slova S (,3S: Sun-Sea-Sand“) označava sunce, more i pesak (kao i seks i alkohol, kako dodaju autori).

Mediteran je često smešten na ivici Evrope, tako da se, ako mu već ne pripada, nalazi na pola puta do egzotičnog orijenta. Još od 17. veka tropska sredina se sve više koristila kao „simbolična lokacija za idealizovane pejzaže i aspiracije zapadnjačke mašte" (Grouv 1995, citirano prema Šeler 2004: 13). Međutim, na Mediteranu koegzistiraju brojne destinacije za odmor, svaka sa svojim kolektivnim imidžom, fantazijama, svakodnevnim radnjama i rutinom, koje Mediteran stavljaju u drugi okvir, kao mesto gde se susrećemo sa civilizacijom i kao mesto za beg od civilizacije (Obrador-Pons i dr. 2009: 16).

\section{Jezik turizma}

Jezik se koristi da bi formirao slike u umovima potrošača, a jedan od načina da se to postigne je upotreba figurativnog jezika u tekstovima. Metafore, koje se koriste da ilustruju turističke proizvode, pomažu potencijalnim klijentima da interpretiraju značenje i konstruišu stvarnost (Džafarova 2012: 37-39). Međutim, prema često citiranom objašnjenju koje daje Dan (1996), jezik turizma je „mnogo više od metafore. Putem statičnih i pokretnih slika, pisanih tekstova i audiovizuelnih sredstava, jezik turizma pokušava da ubedi, da namami, da se udvara i da zavede milione ljudskih bića i da ih, čineći to, pretvori iz potencijalnih u prave klijente" (Dan 1996, citirano prema Razusova 2008: 199). On se nada da će ih na taj način „,isterati iz fotelje i ugurati u avion kako bi ih pretvorio u turi- 
ste“ (Dan 1996, citirano prema Halet i Kaplan-Vajnger 2010: 1-2). S obzirom na to da veći deo retorike prethodi putovanju ili obilasku znamenitosti, Dan dodaje da se može legitmno tvrditi da je turizam utemeljen na diskursu.

Pišući o diskursu u turističkoj ponudi Namibije, Papen (2005: 79) koristi definiciju po kojoj diskursi u turizmu predstavljaju skup izraza, reči, ponašanja, kao i određenih turističkih struktura i aktivnosti koje opisuju mesto i njegove stanovnike.

Iako jezik igra značajnu ulogu u reklamiranju u oblasti turizma, Džafarova i Andersen (2008) smatraju da mu stručnjaci za ovu oblast ne posvećuju dovoljno pažnje, a ta uloga se ne sme potceniti. Polazeći od činjenice da je sistematsko proučavanje diskursa u turizmu započeto relativno kasno, treba istaći da je kritička analiza diskursa u proučavanju turizma neophodna, s obzirom na to da je suština turizma upravo u komunikaciji. Pozivajući se na Danov sociolingvistički koncept jezika u turizmu, Ovsianovska (2011: 232) navodi da jezik modernog doba, promocije i konzumerizma karakterišu opširnost i ubedljivost, pa je istovremeno i izvor društvene kontrole nad turistom-detetom. Jezik turizma se smatra i deskriptivnim jezikom. Osim što predstavlja izvor informacija, može biti pun simboličnih ili prenesenih značenja.

U svom radu „Kako upotreba jezika stimuliše turizam“ (How language use stimulates tourism) Mahadi i Al-Bahrani (2011), sa lingvističkog aspekta i na osnovu njegove povezanosti sa jezikom, turizam percipiraju kao mentalni i realni. Mentalni turizam prethodi realnom i u okviru njega turisti, na osnovu prikazanih slika i tipova izraza koji se koriste u turističkim brošurama prilikom opisivanja destinacija, mogu zamisliti sebe, imati doživljaje ili iskustva kao da se zaista nalaze tamo. S druge strane, u okviru realnog turizma jezik ima ekspresivnu i informativnu funkciju, zadatak da ubedi ili usmeri, s obzirom na to da je reč o samom činu posećivanja mesta i znamenitosti. Kod mentalnog turizma semiotički aspekt jezika je taj koji zavodi i motiviše ljude rečima i slikama da posete određenu destinaciju, dok kod realnog turizma diskurs i stilističke funkcije jezika imaju moć kontrole. Takav jezik ima za cilj i da opusti, zabavi, osveži ili zadovolji turistu. 


\section{Brendiranje destinacije}

Najšire prihvaćena je Akerova (1991: 21) definicija brendiranja, prema kojoj je primarna uloga brenda da identifikuje robu ili usluge jednog ili grupe prodavaca i da diferencira tu robu ili usluge od robe ili usluga konkurenata. Koristeći ovu definiciju kao polazište, Riči i Riči kreiraju definiciju brenda destinacije, kojom pored pojmova identifikacije i diferencijacije obuhvataju i pojmove obećanja (da će putovanje biti nezaboravno), iskustva (koje je na jedinstven način povezano sa destinacijom) i evociranja uspomena (na prijatna iskustva koja su imali na određenoj destinaciji), dodajući da bi u definiciju brendiranja destinacije trebalo uključiti i pojmove imidža destinacije i konkurentnosti (Riči i Riči 1998: 329).

Oni koji se bave marketingom u turizmu, ukoliko žele da prodaju proizvod ili uslugu moraju prezentovati idealizovanu sliku turizma. Turisti žele da dožive slike koje primaju kroz marketinške komunikacione kanale, jer su opsednuti svojim željama iz snova, tako da turizam stvara nerealno okruženje u kom se odigrava fizička aktivnost (Džafarova 2012: 37). Potencijalni turista formira ideju da se zemlja sastoji od idealizovanih mesta koja ga pozivaju da se udalji od svakodnevnog života. U tom smislu može se reći da se imaginarni svet i realnost u turizmu prepliću.

U slučaju Grčke, Stenu (2019: 1654) ističe da u štampi dominira prezentovanje ove zemlje kao destinacije u kontekstu izgubljenog raja, destinacije koja predstavlja sklonište od razvoja metropola, nudeći ljudima primitivnije stilove života. Prema rečima autorke, „bukolički arheološki lokaliteti i izolovana kikladska sela obećavaju da će ispuniti očekivanja, pružajući autentičnu jednostavnost, koja nudi predah od urbane stvarnosti“. Osim toga, često se pominje izgubljena civilizacija koja je, kako se čini, veoma udaljena od savremenog načina života.

\section{Brendiranje Grčke}

Dva dominirajuća imidža Grčke se nisu pojavila istovremeno u istoriji turizma. Antička Grčka i klasična prošlost su protkane po- 
stojanjem moderne grčke države od 1821. godine sve do danas, dok je Egejski arhipelag postao poznat počevši od 1930. godine. Nakon Drugog svetskog rata turizam u Grčkoj je doživeo procvat. Antičko doba i Kikladi su postali sinonimi za grčko poreklo, pa je, zahvaljujući ovim lako prepoznatljivim pojmovima u arhitekturi, Grčka postala popularna destinacija za turiste iz celog sveta (Stenu 2019: 1640).

Iako se u vodičima, katalozima i brošurama insistira na stereotipnim slikama koje su usmeravale pažnju turista na istorijske lokalitete i spomenike, u turizmu je došlo do značajnh promena tokom decenija nakon Drugog svetskog rata. Do 50-ih godina u Grčkoj je preovladavao „kulturni“ turizam, koji je očuvao kontinuitet tradicije putovanja, ustanovljene u 18. i 19. veku. Odlazak u Grčku se mogao okarakterisati kao neka vrsta „hodočašća“ čiji su učesnici želeli da odaju počast mestu koje je iznedrilo zapadnu civilizaciju. Antičkog grčko nasleđe je konceptualizovano kao jedinstvena i nezamenljiva verzija „visoke“ kulture, koja nije bila dostupna narodnim masama. Tokom poslednjih decenija se pokazalo da je duh masovne potrošnje, koja se ogleda u organizovanom turizmu velikih razmera, direktno suprotstavljen „nenadmašivoj jedinstvenosti“ spomenika, te da je ovaj tip turizma pretvorio arheološke lokalitete i spomenike u delove rutinskog itinerera (Galani Mutafi 2004: 171-172). Za razliku od prošlosti kada pristup antičkim lokalitetima nije bio lak, danas su lokaliteti ti koji su se zapravo „prilagodili“ turistima.

Reklamne kampanje Grčke nacionalne turističke organizacije (GNTO), koja je po drugi put osnovana 1950. godine, su, kako navodi Vazu, imale za cilj definisanje grčkog turističkog identiteta i suštine njenog brenda. Prvenstveno su bile usmerene ka stranoj publici, te su i verbalne poruke (kao što su slogani) pisane u najvećoj meri na engleskom, a po potrebi i na drugim jezicima. Slike su uglavnom oslikavale lepotu mora i planinskih predela, međunarodno poznate antičke i vizantijske spomenike, kao što su Akropolj, Delfsko proročište i mnoge vizantijske crkve (od kojih se većina nalazi na Uneskovoj listi svetske baštine), i kosmopolitske destinacije, kao što su ostrva Mikonos, Rodos i Krf. Ovaj pristup brendiranju je zasnovan na konceptu masovnog turizma, koji je po prirodi sezonski i uglavnom je motivisan „3S: Sun-Sea-Sand“ turizmom, a u manjoj meri 
kulturnim turizmom ili ekoturizmom (Lomine i Edmunds 2007, citirano prema Vazu 2014: 42).

Galani Mutafi (2004: 170) navodi da je Grčka nacionalna turistička organizacija koristila promovisanje grčkog antičkog nasleđa kao marketinšku prednost u Evropi, gde mnogi turisti žele da osete duh antike posredstvom materijalnih ostataka svetski poznatih spomenika, koji bi im omogućili da se simbolično povežu sa zapadnom civilizacijom, a samim tim i sa korenima sopstvene istorije i kulture.

Najnoviji slogan grčke turističke promotivne kampanje za svetsko tržište glasi Oh My Greece / Unlock the Feeling. Njen osnovni cilj je da istakne da Grčka ima da ponudi mnogo više od sunca i mora. Grčki turistički proizvod može biti kombinacija prirode, kulture, gastronomije, navika i životnog stila, ali osim toga nudi i nešto direktnije, a to je gostoprimstvo Grka ${ }^{1}$.

Neki od prethodnih slogana su: Greece: Chosen by the Gods (1991-1993), Greece: The authentic choice (1997), Greece: That's life! (1999), Greece: Beyond words! (2002-2003), Elegant Greece (2006), Greece: Explore your senses (2007), Greece: The true experience (2008), Greece: years old. A masterpiece you can afford (2009), Greece: Kalimera! (2010), Greece: Part of Our Soul History (2011), Greece: All time Classic (2013) i drugi (v. Vazu 2014: 43).

\section{Korpus i metodologija}

Ovaj rad se zasniva na analizi korpusa koji uključuje opise Grčke kao turističke destinacije. Kao izvor podataka korišćene su neke od veb-stranica turističkih agencija, koje su bile dostupne nakon unošenja reči letovanje u Grčkoj u Gugl pretraživač. Selektovane su agencije Mouzenidis Travel, Supernova Travel, Dunavturs, Balkan Fun Travel, Monix, Big Blue, Club Paradiso Travel, Robinson, Aqua Travel, Galileo Tours, Lui Travel, Kon Tiki Travel, Barcino Tours, Turisttrade i Sabra Travel. U korpus su uključeni samo opisi Grčke u široj ili kraćoj formi, u kojoj se nalaze na stranicama. Izostavljeni su opisi pojedinih obla-

1 Preuzeto sa https://news.gtp.gr/2019/02/20/new-greek-tourism-campaign -unveiled-oh-my-greece/.13/10/2019. 
sti, ostrva, gradova ili letovališta u Grčkoj za koje su postojali posebni linkovi, kao i opisi tipova smeštaja. Osim navedenih stranica, korišćene su i stranice pretraživača turističkih ponuda Aladin/ Yu Media Group, društvene mreže Travel\&Share i Sat Televizije, na kojima se mogu naći i tekstovi u vidu vesti ili putopisa.

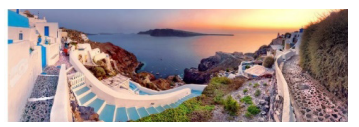

Mouzenidis Travel

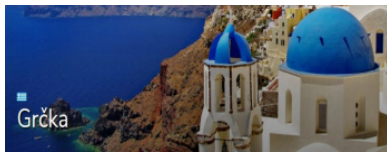

Aqua Travel

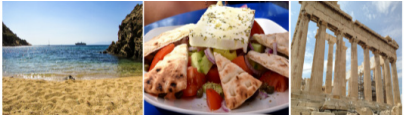

Monix

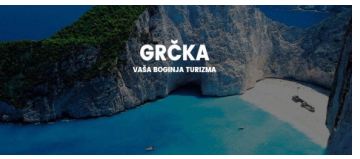

Lui Travel

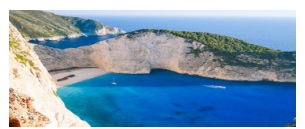

Sabra Travel

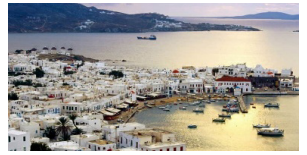

Barcino Tours

Istraživanje je sprovedeno kombinovanjem kvantitativne metode i kvalitativne analize korpusa. Kvantitativni podaci su dobijeni prebrojavanjem sadržajnih reči, odnosno imenica, prideva i glagola, u odabranim tekstovima kako bi se došlo do broja onih koji su najfrekventnije upotrebljeni. Prebrojane reči su tematske i odabrane su od strane autora, te je u izvesnoj meri prisutan faktor subjektivnosti.

U prvom delu istraživanja najfrekventnije reči su klasifikovane na osnovu semantičkih polja kojima pripadaju. Kategorizacija semantičkih polja u slučaju imenica i prideva je preuzeta iz istraživanja Elene Manka (2016: 76), koja ju je koristila pri analizi korpusa u slučaju turističkog diskursa Velike Britanije, Italije i Australije. U drugom delu identifikovane su sintagme u kojima se neke od njih najčešće javljaju, kako bi se ispitalo kako su (strateški) upotrebljene u različitim kontekstima, koji su uslovljeni kombinacijom različitih semantičkih polja. Kod nekih primera je istovremeno ispitano da li i u kojoj meri značenja upravnih reči u okviru sintagmi mogu biti metaforički obojena prisustvom određenih zavisnih reči u promotivne svrhe. Konkretno, u pitanju su tri imenice, tri prideva i tri glagola, koji se nalaze među prvih deset na Tabelama 1, 2 i 3. 


\section{Rezultati}

\subsection{Najfrekventnije imenice}

U Tabeli 1 je prikazano prvih 30 najfrekventnijih imenica, kao i broj ponavljanja svake od njih u korpusu tekstova. Lista obuhvata sve oblike imenica bez obzira na rod, broj ili padež, međutim ne obuhvata reči Grčka i zemlja.

Tabela 1

\begin{tabular}{|l|c|l|c|l|c|}
\hline 1. ostrvo & 59 & 11. leto & 17 & 21. posetilac & 10 \\
\hline 2. more & 50 & 12. turista & 16 & 22. pejzaž & 10 \\
\hline 3. plaža & 30 & 13. vino & 16 & 23. voda & 10 \\
\hline 4. letovanje & 26 & 14. klima & 14 & 24. muzej & 9 \\
\hline 5. obala & 22 & 15. izbor & 12 & 25. istorija & 8 \\
\hline 6. civilizacija & 21 & 16. kolevka & 12 & 26. planina & 8 \\
\hline 7. destinacija & 21 & 17. kuhinja & 12 & 27. manastir & 7 \\
\hline 8. odmor & 20 & 18. maslina & 12 & 28. miris & 7 \\
\hline 9. svet & 20 & 19. mesto & 12 & 29. provod & 7 \\
\hline 10. kultura & 19 & 20. sunce & 11 & 30. ukus & 7 \\
\hline
\end{tabular}

Pored imenica, koje se nalaze u tabeli, navešćemo i imenicu zaliv koja se u korpusu takođe javlja sedam puta, a zatim i one imenice koje se javljaju: a) šest puta (9), b) pet puta (10), c) četiri puta (14), d) tri puta (12) ili e) dva puta (7). A to su:

a) bog, demokratija, prijatelj, sirtaki, smeštaj, buzuki, pogled, ponuda, ulje

b) čulo, hotel, mit, porodica, sećanje, specijalitet, spomenik, temperatura, zalazak, značaj

c) apartman, hrana, izlet, legenda, muzika, nasleđe, plavetnilo, gostoprimstvo, igra, lepota, nebo, raj, sadržaj, šarm

d) arhitektura, blago, bogatstvo, bor, nalazište, obilazak, piće, prijateljstvo, prošlost, taverna, umetnost, žurka

e) beskraj, izazov, mešavina, pesak, popularnost, različitost, zelenilo 
Na osnovu tabele može se zaključiti da najveći broj najfrekventnijih imenica pripada semantičkom polju „životne sredine“, a neke od njih su ostrvo (59), more (50), plaža (30), obala (22), klima (14), sunce (11), pejzaž (10), voda (10) i planina (8). Drugo semantičko polje sa najvećim brojem primera jeste polje „kulture i nasleđa“, kome pripadaju imenice civilizacija (21), kultura (19), kolevka (12), muzej (9), istorija (8) i manastir (7). Za njima po brojnosti sledi polje „aktivnosti“ u koje bi se mogle svrstati imenice letovanje (26), odmor (20), izbor (12) i provod (7).

Osim ovih semantičkih polja javljaju se i polje „opšte lokacije“ sa imenicama destinacija (21), svet (20) i mesto (12), zatim polje „hrane i restorana“ sa imenicama vino (16), kuhinja (12), maslina (12), miris (7) i ukus (7), polje „ljudi“ sa imenicama turista (16) i posetilac (10) i polje koje se odnosi na „vreme“ sa imenicom leto (17).

\subsection{Najfrekventniji pridevi}

U Tabeli 2 je prikazano prvih 30 najfrekventnijih prideva, kao i broj ponavljivanja svakog od njih u korpusu tekstova. Prilikom brojanja je izostavljen pridev grčki. Lista obuhvata sve oblike prideva bez obzira na rod, broj ili padež, dok se oblici superlativa nekih prideva navode kao poseban primer, jer imaju specifičnu namenu i funkciju u okviru reklamnog diskursa, o čemu će biti reči u nastavku.

Tabela 2

\begin{tabular}{|l|l|l|l|l|l|}
\hline 1. star & 14 & 11. arheološki & 8 & 21. tirkizan & 7 \\
\hline 2. mediteranski & 13 & 12. bogat & 8 & 22. zanimljiv & 7 \\
\hline 3. tradicionalni & 13 & 13. drevni & 8 & 23. jedinstven & 6 \\
\hline 4. antički & 12 & 14. istorijski & 8 & 24. kulturni & 6 \\
\hline 5. nezaboravan & 11 & 15. najstariji & 8 & 25. maslinov & 6 \\
\hline 6. plav & 11 & 16. peščani & 8 & 26. olimpijski & 6 \\
\hline 7. beo & 10 & 17. predivan & 8 & 27. prelep & 6 \\
\hline 8. lep & 10 & 18. topao & 8 & 28. dobar & 5 \\
\hline 9. poznat & 10 & 19. letnji & 7 & 29. idealan & 5 \\
\hline 10. turistički & 10 & 20. najlepši & 7 & 30. moderan & 5 \\
\hline
\end{tabular}


Pored prideva iz tabele navešćemo i preostale prideve, koji se u korpusu javljaju: a) pet puta (6), b) četiri puta (8), c) tri puta (13) ili d) dva puta (12). A to su:

a) mnogobrojan, morski, povoljan, prijatan, prirodni, savršen

b) divan, opušten, planinski, romantičan, specifičan, sunčan, širok, značajan

c) beskrajan, kristalan, lokalni, najatraktivniji, najpopularniji, nestvaran, noćni, pravoslavni, raznovrstan, skriven, veličanstven, čist, živopisan

d) dijamantski, fascinantan, gostoprimljiv, ljubazan, najsunčaniji, neprocenjiv, netaknut, odličan, pomešan, popularan, porodičan, sjajan

Na osnovu tabele može se zaključiti da najveći broj najfrekventnijih prideva pripada semantičkom polju „vremena“, sa pridevima star (14), antički (12), drevni (8), istorijski (8), najstariji (8), letnji (7) i moderan (5). Za njim slede semantičko polje „jedinstvenosti i poželjnosti“ kome pripadaju pridevi nezaboravan (11), turistički (10), bogat (8), zanimljiv (7), jedinstven (6) i dobar (5), a zatim i polje „lepote“ sa pridevima lep (10), predivan (8), najlepši (7), prelep (6) i idealan (5). Semantičkom polju „boja“ pripadaju pridevi plav (11), beo (10) i tirkizan (7), a polju „kulture i nasleđa“ pridevi tradicionalni (13), arheološki (8) i kulturni (6). Pridevi mediteranski (13) i olimpijski (6) pripadaju polju „opšte lokacije“, a pridevi peščani (8) i topao (8) semantičkom polju „životne sredine“. Za polje „popularnosti“ vezuje se pridev poznat (10), a za polje gastronomije pridev maslinov (6).

Potencijalni turisti veruju da je ono što se opisuje poželjno i da se mora videti zahvaljujući velikoj frekventnosti superlativa i izraza koji imaju evaluativnu funkciju, kao što su ,jedan od svetski+superlativ“, „svetski poznat“, „, svetske klase“, „, superlativ+u Grčkoj", koji opisuju jedinstvenost i status (Manka 2016: 74). Nekoliko takvih primera se može naći i u našem korpusu, kada se navodi da je Grčka jedna od: najatraktivnijih turističkih destinacija Evrope, najpopularnijih destinacija za letnji odmor, najbezbednijih zemalja na svetu, etnički najčistijih država na svetu itd. Pored toga, pridevi koji su se najčešće javljali u superlativu su: najstariji, najlepši, najatraktivniji, najpopularniji i najsunčaniji. 
6.2.1. Najfrekventniji glagoli

U Tabeli 3 je prikazano prvih 30 najfrekventnijih glagola, kao i broj ponavljivanja svakog od njih u korpusu tekstova. Lista obuhvata sve oblike glagola bez obzira na lice i vreme, dok su se svršeni i nesvršeni vid istog glagola posmatrali kao jedna leksička jedinica. Pomoćni i modalni glagoli nisu uračunti.

Tabela 3

\begin{tabular}{|l|c|l|c|l|l|}
\hline 1. imati & 20 & 11. (po)nuditi & 6 & 21. obasjavati & 3 \\
\hline 2. predstavljati & 13 & 12. doživeti & 5 & 22. pogledati & 3 \\
\hline 3. nalaziti (se) & 12 & 13. želeti & 5 & 23. probati & 3 \\
\hline 4. uživati & 11 & 14. letovati & 4 & 24. pronaći & 3 \\
\hline 5. zapljuskivati & 10 & 15. odlučiti & 4 & 25. upoznati & 3 \\
\hline 6. smatrati (se) & 9 & 16. odoleti & 4 & 26. videti & 3 \\
\hline $\begin{array}{l}\text { 7. birati/izabrati/ } \\
\text { odabrati }\end{array}$ & 8 & 17. privlačiti & 4 & 27. istraživati & 2 \\
\hline 8. posetiti & 8 & 18. propustiti & 4 & 28. obilovati & 2 \\
\hline 9. provoditi/provesti & 8 & 19. igrati & 3 & 29. opredeliti se & 2 \\
\hline 10. osetiti & 7 & 20. iskusiti & 3 & 30. stimulisati & 2 \\
\hline
\end{tabular}

Na vrhu tabele nalaze se glagoli kao što su imati (20), predstavljati (13), nalaziti (se) (12) i smatrati (se) (9), koji imaju informativnu funkciju, što je očekivano s obzirom na prirodu teksta. Međutim, najbrojniji su glagoli koji se odnose na posećivanje i doživljavanje iskustava na određenoj destinaciji, kao što su uživati (11), posetiti (8), provoditi/provesti (8), osetiti (7), doživeti (5), letovati (4), iskusiti (3), pogledati (3), probati (3), pronaći (3), upoznati (3), videti (3) i istraživati (2). Zatim se mogu uočiti oni koji podstiču na preduzimanje akcije ili pravljenje izbora, naročito u kontekstu prodaje aranžmana od strane agencije, kao što su birati /izabrati/ odabrati (8), (po)nuditi (6), želeti (5), odlučiti (4), propustiti (4) - koji se obično koristi uz negaciju, opredeliti se (2) i stimulisati (2). Pojedini glagoli upućuju na lepotu i atraktivnost destinacije, kao što su zapljuskivati (10) - što asocira na more, odoleti (4), privlačiti (4), obasjavati (3) - koji asocira na sunce, i obilovati (2) ili bavljenje fizičkom aktivnošću - igrati (3). 
Glagoli igraju važnu ulogu u turističkom diskursu, jer doprinose na određeni način ubedljivosti svih reklamnih turističkih tekstova. Oni mogu davati instrukcije ili savete turistima u vezi sa aktivnostima kojima bi mogli da se bave (Manka 2016: 78). Sugestivnost se postiže pre svega upotrebom imperativa, ali i upotrebom glagola nuditi ili pružati u prezentu ili glagolom trebati.

\section{Analiza diskursa}

Cilj svakog promotivnog diskursa je da privuče pažnju i interesovanje potencijalnih turista. To se može postići strateškom upotrebom reči koje ističu jedinstvenost, status ili značaj destinacije u određenom vremenskom periodu (Manka 2016: 65). Stoga lingvistička analiza promotivnog diskursa treba da se fokusira na imenice i prideve koji se odnose na popularnost destinacije. Želja za putovanjem kod turista se može probuditi i upotrebom imenica i prideva koji se odnose na lepotu destinacije, kao i opisima koji predstavljaju destinaciju idealnom za određene aktivnosti ili posebne grupe turista (kao što su porodice, deca, ljubitelji surfovanja itd.).

Ubedljivo najfrekventnija imenica u korpusu je imenica ostrvo. Ona se ovde najčešće javlja nakon osnovnih brojeva, imenice mnoštvo ili prideva prelepo i rajsko. Ostrva na poseban način utiču na zamišljanje raja, zbog njihovih svojstava, kao što su „odvojenost, ekskluzivnost i holizam, koja se ponekad u evropskoj misli opisuju kao 'logika ostrva'“ (Grin 2000, citirano prema Šeler 2004: 13). U skladu sa navedenim, i Šeler (2004) zaključuje da zelene šume, egzotična flora i tropsko zelenilo predstavljaju simbole Edenskog vrta koji je zamišljen pre dolaska Evropljana na tlo Novog sveta. Fizičke karakteristike ostrva, kao što su netaknute plaže, čisto more i atraktivna klima, kojima se „naglašava intimna veza između kopna i mora koje ih okružuje", svakako su njegove najprivlačnije karakteristike, s obzirom na to da predstavljaju prirodne i kulturne atrakcije. Ovde treba pomenuti i manje opipljiv aspekt doživljaja ostrva, koji čine, između ostalog, osećaji udaljenosti, ekskluzivnosti, odvojenosti, tradicije, a koji se u literaturi naziva „islandness” (Šarpli 2004: 
23). Metaforičkom upotrebom prideva rajsko uz imenicu ostrvo formira se koncept da je (tropsko) ostrvo raj.

Druga imenica po frekventnosti je imenica more, koja se u korpusu javlja uz prideve: toplo, tirkizno, predivno, azurno plavo, čisto, nezagađeno, najlepše, smaragdno, kristalno-plavo, sjajno itd. Termini za boje se ponekad ne koriste samo zbog njihove preciznosti, već zbog njihovih perifernih asocijacija. Primeri za to su pridevi tirkizno, smaragdno i kristalno-plavo, koji demonstriraju da su asocijacije važnije od vrednosti informacije (Stajnval 2002: 144). Naime, upotrebom reči koje označavaju drago kamenje, kao što smaragd i kristal, postiže se utisak dragocenosti i retke lepote. Pridev azurni se može povezati sa lapis lazuli ili lazuritom, poludragim kamenom od kog se dobija plava boja. Prošaran je belim tragovima kalcita i zlatnim zrncima pirita, zbog čega podseća na zvezdano nebo, a prisustvo pirita mu podiže kvalitet, lepotu i vrednost. S obzirom na to da se drago kamenje koristi u izradi skupog i poželjnog nakita, njegovom metaforičkom upotrebom u opisu pejzaža naglašava se osećaj luksuza i formira se koncept da su elementi pejzaža dragulji (Javorska 2017: 21).

Treća po frekventnosti je imenica plaža. Kako navodi Šilds (2004: 44), u literaturi o turizmu imidž „dobre plaže” je povezan sa peskom, a tipično ponašanje na plaži se interpretira kao neka vrsta razonode, koja može biti i aktivna uz odbojku na plaži, ili pak trčanje ili skupljanje školjki. Slike aktivnosti na plaži koje dominiraju su one na kojima se prikazuju sunčanje, opružena tela, osoba koja čita pod suncobranom ili na plaži, ili grupa ljudi koja sedi na pikniku. Imenica plaža se u korpusu javlja uz prideve: lepa, živopisna, široka, pitoma, jedinstvena, izuzetna, peščana, stenovita, predivna, beskrajna, duga, prelepa, mirna, izolovana, skrivena itd. Gotovo svi pridevi pripadaju semantičkim poljima lepote i jedinstvenosti i poželjnosti.

Najfrekventniji pridevi pripadaju semantičkom polju „vremena", što ukazuje na tendenciju naglašavanja večitog značaja zemlje, sa namerom da se privuku turisti. Frekventnost ovih prideva je često povezana sa frekventnošću imenica koje pripadaju semantičkom polju „kulture i nasleđa“, koje takođe igra važnu ulogu u promovisanju Grčke kao turističke destinacije. Kao primer za to može 
se navesti pridev antički koji prati imenice: civilizacija, predak, iskopina, ruševina, kultura i spomenik. Zanimljiv je podatak da se pridev tradicionalni iz istog semantičkog polja u najvećem broju slučajeva sreće pored imenica kao što su specijalitet, jelo, selo, poslastica, kuhinja i ishrana, koje pripadaju semantičkom polju hrane i restorana. Grčka tradicionalna kuhinja je srodna srpskoj, pa se može reći da se na ovaj način turistima sugeriše da „neće ostati gladni“, odnosno da će se na meniju sigurno naći neko jelo poznatog ukusa.

Među prvih deset prideva na Tabeli 2 nalaze se i dva prideva iz semantičkog polja „boja“: plav i beo. Pridev beo se u korpusu najčešće koristi uz imenice: kuća, mermer, građevina, grad, pesak, šljunak i vino. Bela boja, koja dominira na starinama i u kikladskoj arhitekturi, vekovima je u mnogim civilizacijama bila simbol večnosti i univerzalni sinonim za duhovnu čistoću, idealizaciju, čistoću prošlosti, dok se u evropskim kulturama bela boja vezuje za vrednosti kao što su jasnoća i transparentnost (Stenu 2019: 1653). Međutim, dominacija bele boje u Grčkoj pripada novijoj istoriji. Naime, diktator Joanis Metaksas (1936-1941) je uputio dekret stanovnicima kikladskih ostrva zahtevajući da okreče kuće u belo kao mera zaštite javnog zdravlja, s obzirom na to da je u Grčkoj u to vreme vladala epidemije kolere (Stenu 2019: 1641).

Kada je reč o glagolima, pomenućemo nekoliko koji spadaju u najbrojnije, a odnose se na posećivanje i doživljavanje iskustava na određenoj destinaciji. Glagol uživati se koristi sa predloško-padežnim konstrukcijama, kao što su: u aromama izvanrednih grčkih vina, u svakom trenutku, u ostacima neprevaziđene kulture i istorije, u životu, u predstojećem letu, u jedinstvenom šarmu, u romantičnim zalascima sunca, u ludom noćnom provodu. Nakon glagola osetiti (se) slede objekatske sintagme: pravi duh Grčke, atmosferu drevne kulture, kao kod kuće, a posle glagola posetiti se navodi: neki od muzeja, Grčku, zemlju maslina, ostrva, najbolja mesta u Grčkoj, bele gradove itd. Iz navedenih primera može se zaključiti da se radnje prenose na imenice koje prvenstveno pripadaju semantičkom polju,,kulture i nasleđa“, ali i poljima „životne sredine“ i „aktivnosti“. Ova konstatacija je u skladu sa dosadašnjom politikom Grčke nacionalne turističke organizacije, koja obuhvata obe kategorije projektovanog imidža Grčke. 


\section{Zaključak}

U ovom radu fokus je bio na identifikaciji lingvističkih šablona u reklamnom diskursu dostupnom na veb-stranicama više srpskih turističkih agencija, kao i na veb-stranicama jednog pretraživača turističkih ponuda, jedne društvene mreže i jedne televizije, na kojima se mogu naći i tekstovi u vidu vesti ili putopisa, na kojimase promoviše brend Grčke. Činjenica je da upotrebom adekvatnog diskursa tekstovi iz korpusa dobijaju na ubedljivosti, koja privlači pažnju potencijalnih turista, stimuliše njihovo interesovanje, čini turistički proizvod poželjnim i na kraju ih ubeđuje da ga kupe.

Kada se uzmu u obzir kvantitativni rezultati istraživanja prikazani u tabelama, može se zaključiti da se u promotivnim tekstovima o Grčkoj, kada je reč o imenicama, ubedljivo najviše koriste one koje pripadaju semantičkom polju „životne sredine“ (npr. ostrvo, more, plaža), dok su nešto manje brojne one koje pripadaju semantičkom polju „kulture i nasleđa“ (npr. civilizacija, kultura, muzej) i polju „aktivnosti“ (npr. letovanje, provod). Kada je reč o pridevima, najveći broj najfrekventnijih prideva pripada semantičkom polju „vremena" (npr. star, antički, istorijski), a za njim slede semantičko polje „jedinstvenosti i poželjnosti“ (npr. nezaboravan, zanimljiv, jedinstven) i polje „lepote“ (npr. lep, predivan, idealan). Pored glagola koji se koriste najčešće u kontekstu pružanja informacija o destinaciji (npr. predstavljati, nalaziti se), najbrojniji su glagoli koji se odnose na posećivanje i doživljavanje iskustava (npr. uživati, posetiti, osetiti, doživeti). Upoređivanjem i ukrštanjem dobijenih rezultata mogao bi se složiti poput mozaika lingvistički šablon koji se pojavljuje u turističkoj ponudi za srpske turiste, a to je da im se nude predivna grčka ostrva sa morem i plažama jedinstvene lepote u kojima se može uživati, a to se iskustvo može upotpuniti posećivanjem muzeja u kojima se mogu videti ostaci antičke civilizacije. Ovakav koncept turističke ponude ujedno je i rezultat dugogodišnje politike i reklamne kampanje Grčke nacionalne turističke organizacije, u skladu sa kojima je „Grčka ustanovljena kao destinacija za letnji odmor, koja verno čuva svoju reputaciju 'kolevke zapadne civilizacije'“ (Vazu 2014: 42). 
Nakon što su u drugom delu istraživanja identifikovane sintagme u kojima se neke od najfrekventnijih imenica, prideva i glagola javljaju, kvalitativnom analizom je ispitana njihova primena u različitim kontekstima. Zaključeno je da postoje izvesne pravilnosti ili klišei u slučaju kombinovanja reči iz različitih semantičkih polja. Analizom pojedinih primera istovremeno je zaključeno da su značenja upravnih reči u okviru sintagmi metaforički obojena prisustvom određenih zavisnih reči (npr. u slučaju imenica ostrvo i more) sa ciljem da kod potencijalnog turiste probude želju da otputuje na konkretnu destinaciju i tamo vidi i iskusi ono što mu se prezentuje u reklamnom diskursu. U ovom slučaju to je ono što čini suštinu brenda Grčke - kristalno čista voda, plaže okupane suncem, antička kultura, prirodna bogatstva i sveta mesta (Vazu 2014: 43).

\section{LITERATURA}

Aker 1991: Aaker, D.A. Managing Brand Equity. New York: The Free Press. Dan 1996: Dann, G. The language of tourism: a sociolinguistic perspective. UK: CAB International.

Džafarova 2012: Djafarova, B. E. The Role of Figurative Language Use in the Representation of Tourism Services, Athens Journal of Tourism, $\mathrm{X}, \mathrm{Y}, 1-15$.

Džafarova i Andersen 2008: Djafarova, E. \& Andersen, H. C. The Contribution of Figurative Devices to Representation of Tourism Images, Journal of Vacation Marketing, 14, 4, 291-303.

Galani Mutafi 2004: Galani-Moutafi, V. Tourism research on Greece: A critical overview, Annals of Tourism Research, 31, 157-179.

Grin 2000: Green, R. Island Logic, in: P. Hulme, W. H. Sherman (eds.), „The Tempest" and Its Travels, Philadelphia, PA: University od Pennsylvania Press, 138-145.

Grouv 1995: Grove, R. Green Imperialism: Colonial Expansion, Tropical Island Edens and the Origins of Environmentalism, 1600-1860. Cambridge, Cambridge University Press.

Halet i Kaplan-Vajnger 2010: Hallett, R. W. \& Kaplan-Weinger, J. Official Tourism Websites: A Discourse Analysis Perspective. Bristol: Channel View.

Javorska 2017: Jaworska, S. Metaphors we travel by: a corpus-assisted study of metaphors in promotional tourism discourse, Metaphor and Symbol, 32, 3, 161-177. 
Lomine i Edmunds 2007: Lominé, L., \& Edmunds, J. Key concepts in tourism. New York: Palgrave Macmillan.

Mahadi i Al-Bahrani 2011: Mahadi, T. S. \& Al-Bahrani, R. H. How Language Use Stimulates Tourism, Language in India, 11, 12, 352-374.

Manka 2016: Manca, E. Persuasion in Tourism Discourse: Methodologies and Models. Cambridge: Cambridge Scholars Publishing.

Mek Kanel 2002: Maccannell, D. The Ego Factor in Tourism, Journal of Consumer Research, 29, 1, 146-151.

Obrador-Pons i drugi 2009: Obrador-Pons, P., Crang, M. and Travlou, P. Taking Mediterranean tourists seriously, in Cultures of mass tourism: doing the Mediterranean in the age of banal mobilities. Farnham: Ashgate, 1-27.

Ovsianovska 2011: Owsianowska, S. Tourism Promotion, Discourse and Identity,Folia Turistica, 25, 1, 231-248.

Papen 2005: Papen, U. Exclusive, ethno and eco: representations of culture and nature in tourism discourses in Namibia, in A. Jaworski, A. Pritchard (eds.) Discourse, communication and tourism, Clevedon: Channel View Publications, 79-97.

Razusova 2008: Rázusová, M. The Language of Tourism, 198-201. [https://www.pulib.sk/web/kniznica/elpub/dokument/Ferencik2/subor/27.pdf], (pristupljeno 6.10.2019).

Riči i Riči 1998: Ritchie J. R. B, Ritchie R. J. B. The branding of tourism destinations: past achievements and future challenges. Keynote address, Annual Congress of the International Association of Scientific Experts in Tourism (AIEST), September 1998, Marrakesh, Morocco: 89-116.

Stajnval 2002: Steinvall, A.English Colour Terms in Context. Umeå: Umeå universitet.

Stenu 2019: Stenou, M. (2019): Live Your Myth in Greece: Towards the Construction of a Heritage Identity, in Heritage2019 [Online], 2, 16401661. [https://doi.org/10.3390/heritage2020101] (pristupljeno 14.10.2019).

Šarpli 2004: Sharpley, R. Islands in the sun: Cyprus, in M. Sheller, J. Urry (eds.) Tourism Mobilities: Places to Play, Places In Play. London: Routledge, 22-31.

Šeler 2004: Sheller, M. Demobilizing and remobilizing Caribbean paradise, in M. Sheller, J. Urry (eds.) Tourism Mobilities: Places to Play, Places In Play. London: Routledge, 13-21.

Šilds 2004: Shields, R. Surfing:global space or dwelling in the waves?,in M. Sheller,J. Urry (eds.), Tourism Mobilities: Places to Play, Places In Play. London: Routledge, 44-51. 
Vazu 2014: Vazou, E. From Posters to Posts: Greece Moves Beyond Tourism Campaigns to e-Destination Branding, International Journal of Cultural and Digital Tourism 1, 1,38-52.

\section{IZVORI SA INTERNETA}

https://www.mouzenidis.com/sr-rs/greece/article/about-greece https://www.supernovatravel.rs/aranzman/letovanje/grcka-apartmani http://www.dunavturs.com/ponude/leto-2019/grcka/ https://balkanfun.travel/putovanje/grcka-leto http://monix.rs/vodic-kroz-grcku/ https://www.bigblue.rs/sr/location/grcka https://www.paradisotravel.com/letovanje-grcka.html https://www.robinson.rs/grcka-leto-2018/1 https://www.aquatravel.rs/letovanje/grcka https://galileotours.rs/grcka/ https://luitravel.rs/grcka/ https://www.kontiki.rs/sr/location/grcka https://www.barcino.travel/leto-grcka-apartmani http://www.turisttrade.com/grcka.html https://putovanja.aladin.info/grcka/ https://www.letovanje-lastminute.com/grcka/ https://travelandshare.info/drzava/grcka/ http://www.sattelevizija.com/vesti/jedna_vest/zasto_je_grcka_i_dalje jedna od najboljih destinacija za letovanje 19621100821 


\title{
Dina Dmitrović
}

\section{IN SEARCH OF A LOST PARADISE: GREECE AS A BRAND IN PROMOTIONAL DISCOURSE OF SERBIAN TOURIST AGENCIES}

\begin{abstract}
Summary
In an era of globalization and expansion of tourism, the marketization of public discourse and the growing impact of the media, the Internet in particular, result in the firmer grounding of tourism as discourse (Rázusová 2008: 199). Brochures, travel guides and websites available to tourists shape their expectations long before they arrive at their destination (Hallet \& Kaplan-Weinger 2010: 2). The fact that Greece is traditionally the most popular summer holiday destination in Serbia inspired the author to investigate the language used in promotional discourse by Serbian travel agencies from a linguistic perspective. In the first part of the empirical research, after using the quantitative method the most frequent nouns, adjectives and verbs were identified in the corpus of texts compiled mostly from the web sites of tourist agencies. Later those words were classified into categories according to their semantic fields. In the second part of the research some of the most frequent nouns, adjectives and verbs were identified in different word clusters in order to investigate how they are used in different contexts. The results showed certain regularities in cases of combining words from different semantic fields. After analyzing several clusters it was also concluded that the meanings of their core words were influenced by elements of figurative language (e.g. in cases of nouns island and sea), in order to "spark" a potential tourist's desire to travel to a certain destination and simultaneously see or experience what is presented to him through the tourism discourse. The concept of the present tourist offer is a result of advertising campaigns conducted over the years by the Greek National Tourist Organization, according to which „Greece has been established as a summer holiday destination, faithfully preserving its reputation as the 'cradle of western civilisation'“ (Vazou 2014: 42).
\end{abstract}

Key words: promotional discourse, language of tourism, destination, branding, corpus analysis, semantic field 